\title{
Unilateral Option Clauses: The Way Forward
}

\author{
Salonee Patil*
}

\begin{abstract}
India is on its way to being recognised as one of the arbitration-friendly nations of the world. An unresolved question of law, acting as a hurdle to this is the enforceability of option clauses. Since arbitration agreements are the foundation of the rights of the parties to an agreement, it is to be considered whether unilateral option clauses are valid because the parties have agreed to the same. This paper analyses the consequences of only one party to a contract having the right to approach a broader choice of forum to hear its grievances. Although unilateral option clauses are commonly used in commercial transactions, they pose various issues. This paper examines the different facets of the validity and operation of such clauses in arbitration. For this, the paper relies on the developments in Indian as well as international arbitration laws-specifically, the recent judgement of the Singapore Court of Appeals is examined. The issues with respect to enforceability of such clauses make it necessary to weigh the benefits of having them, as against their complex operability.
\end{abstract}

Keywords: Arbitration Agreement, International Commercial Arbitration, Mutuality, Procedural Equality, Unilateral Option Clauses

\section{Introduction to Option Clauses}

Dispute resolution clauses in contracts are usually either Arbitration clauses or Jurisdiction clauses. The former refers the

*ILS Law College, Pune, India; saloneepatil1@gmail.com. 
parties to arbitration and the latter confers jurisdiction to a particular competent court. However, there also exist hybrid dispute resolution clauses where the party/parties may choose between arbitration and litigation. The choice may either be given to one party or both the parties to the contract. This distinguishes the above mentioned dispute resolution clauses into two types Unilateral and Bilateral option clauses. Bilateral option clauses give both the parties to the contract, an option to choose any of the methods of dispute resolution as indicated in the clause. Whereas, Unilateral option clauses confer such a right to choose, on only one of the parties to the contract.

\section{Bilateral Option Clauses}

A common issue with the enforceability of bilateral option clauses is the underlying element of uncertainty in referring the disputes to arbitration. Many a times, parties underestimate the need to form an arbitration clause that is clear, precise, and certain. This mistake can be detrimental to them, and this is why the law necessitates certainty and absoluteness when it comes to arbitral references. The use of words like 'may' and 'can' has frequently resulted in adverse consequences to the parties as against the use of more determinative words like 'shall'.

In a recent case ${ }^{1}$ in Hong Kong, the court held that, in spite of using the word 'may' in the arbitration clause, if the intention of the parties is clear that the matter is to be referred to arbitration, the arbitration will be valid. This means that, such a clause allows either party to commence litigation - if this occurs, the other party may still request that the proceedings be stayed, in which case both the parties are bound to honour the agreement to initiate arbitration. So the word 'may' effectively becomes the word 'shall', where the clause provided that if, 'settlement cannot be reached through consultations the matter may be submitted for arbitration'. ${ }^{2}$

\footnotetext{
${ }^{1}$ Anzen Ltd. v. Hermes One Ltd., (2016) UKPC 1.

2 China State Construction Engineering Corporation Guangdong Branch v.Madiford Ltd.,(1992) 1 HKC 325.
} 
The courts in India for a long time, denied the validity of clauses which contained uncertain words like 'may' with regard to reference to arbitration-for instance, clauses like 'either of the parties may refer the dispute to arbitration'. Ambiguity is not permitted and certainty is a must. However, recently, in the case of Marco Polo Restaurant, ${ }^{3}$ the Calcutta High Court established that, as long as certainty is evident, the use of uncertain words will not render an arbitration agreement void. However, one must use such words sparingly and cautiously as it may result in unnecessary costs and delay if any one of the parties commence litigation. The other party will have to obtain a stay and significant wastage of time and cost will be borne by both the parties. And, no one will be able to seek compensation from the other, for the costs borne as their rights are reflected in the clause and each party was acting in furtherance of their right as conferred by the clause.

\section{Unilateral Option Clauses}

Most commercial contracts are equipped with an arbitration clause that will ensure resolution of disputes in a way that is mutually agreed upon by the parties. An arbitration clause provides for seat, venue and applicable law, amongst other things. The growth of foreign investment has witnessed a steady growth of the use of unilateral option clauses in international commercial contracts. Usually, the party with bargaining power reserves the right to choose between a wider choice of approachable forums to settle its disputes, as against the weaker party.

Hybrid jurisdiction clauses are common place in commercial contracts. They are included in various financing agreements and debt and equity market transaction documents worldwide. Such clauses enable the party having the option to commence litigation to obtain summary or default judgment (which are not available in arbitration), or to resort to arbitration because a court judgment may not be enforceable in the jurisdiction of the counterparty or where its assets are located.

3 Suresh Tulshan v. Marco Polo Restaurant Pvt. Ltd.,G.A.No. 2827 of 2013 :C.S.No. 221 of 2013 (Original Side). 
This is particularly the case if the local courts in the jurisdiction in which the counter party has assets would not recognize a foreign court's judgment. If the counterparty's jurisdiction has ratified the New York Convention, ${ }^{4}$ an arbitral award may be more easily enforceable internationally than a judgment of a foreign court, which depends on the existence of bilateral or multilateral treaties for reciprocal enforcement. The risks of cross-border lending would significantly increase if a unilateral right to refer a dispute to arbitration is not recognized because the lender would be unable to enforce a judgment for unpaid amounts in the jurisdiction in which the counterparty's assets are located. ${ }^{5}$

\section{Position of English Courts}

In a decision ${ }^{6}$ rendered by the Court of Appeals in 1948 in England, it was held that, a unilateral option clause in a contract for storage of goods in a warehouse was valid. The clause stated that, any claim by the customer but not any claim by the warehouse keeper could be referred to arbitration.

This decision was cited and followed in the subsequent decision of Pittalis $v$. Shorefettin ${ }^{7}$ which was regarding a unilateral option clause in a lease deed and the element of mutuality was interpreted in it. The Court held that, the clause conferring a right on the tenant to refer the dispute to an independent surveyor was in fact bilateral as both sides accepted the agreement. The fact that only one of the parties had such a right was irrelevant. It was held that, there was nothing in the unequal operation to divest it of the character of an arbitration clause. Even otherwise, there was no lack of mutuality in the clause.

\footnotetext{
${ }^{4}$ Convention on the Recognition and Enforcement of Foreign Arbitral Awards, New York Convention, 1958, http://www.uncitral.org/uncitral/en/uncitral_texts/arbitration/NYCon vention.html.

${ }^{5}$ International Chamber of Commerce (ICC), Document No.470/1248rev, 4, \ 2.

${ }^{6}$ Woolf v. Collis Removal Service, (1948) 1 KB 11.

7Pittalis v. Shorefettin, (1986) 1QB 868.
} 
In NB Three Shipping $v$. Harebell Shippings, the Court confirmed the previous case. The arbitration clause gave the owners in the charter party exclusive rights to choose to arbitrate in London. The charterers initiated proceedings in the English Court and the owners subsequently brought a claim of arbitration. It was held that, the suit must be stayed and the parties can proceed with the arbitration.

\section{Position in India}

Neither the Arbitration Act $^{9}$ nor the Supreme Court has taken a particular stand on the validity of unilateral option clauses in India. However, a number of High Courts have decided on this issue. The recognition of unilateral option clauses in India can be traced back to $1991^{10}$ and can still be found to be prevalent despite the nonuniformity in judicial precedents.

\section{1 Bhartia Cutler Hammer Case}

In a case before the Delhi High Court11, the plaintiff, Bhartia Cutler Hammer Ltd. approached the court when the defendant failed to furnish sales-tax form and pay for the equipment supplied by the plaintiff. The defendant argued that the plaintiff should have proceeded with arbitration as their contract provided for resolution of disputes by arbitration and invoked the arbitration clause. The plaintiff denied the validity of the clause and argued that even if it is presumed that the arbitration clause in the agreement is valid, that clause being unilateral cannot be enforced as it gives power only to the defendant for referring disputes to arbitration. It denies the same right to the plaintiff, therefore, this clause is bad in law and cannot be called an arbitration clause. Moreover, the dispute of the applicant did not fall in the scope of the arbitration agreement. The clause reads as follows:

\footnotetext{
${ }^{8}$ NB Three Shipping v. Harebell Shipping, (2005) 1 Lloyd's Rep. 509.

${ }^{9}$ The Arbitration and Conciliation Act, 1996.

${ }^{10}$ Bhartia Cutler Hammer Ltd. v.Avn Tubes Ltd., (1993) BC 472.

${ }^{11} I d$.
} 


\begin{abstract}
18. Arbitration - Without prejudice to the above Clause 17, of the contract the Company, M/s. Avn Tubes Limited, reserves its right to go in for arbitration, if any dispute so arisen is not mutually settled within 3 months of such notice given by the Company to the Contractor. And, the award of the Arbitrator, to the appointed by the Company, M/s. Avn Tubes Limited, shall be final and binding on both the Company and the Contractor.
\end{abstract}

The plaintiff relied on the case of Baron $v$. Sunderland Corporation 12 in which the question of want of mutuality was examined by the Court of Appeal and was held that, mutuality is an essential ingredient in arbitration.

The plaintiff further relied on the decision of the Calcutta High Court in the case of Union of India $v$. Ratilal R. Taunk ${ }^{13}$ where the court considered whether an arbitration agreement is unilateral if only one of the parties has the option to refer the disputes to arbitration and whether such option has legal validity at the instance of other parties. It was held that, according to Section 2(a) of the Arbitration Act ${ }^{14}$ 1996, when an arbitration agreement gives an option or liberty to only one of the parties to agree to submit, present or future differences to arbitration, it is not an arbitration agreement, there must be an unqualified or unconditional agreement in favour of all the parties to exercise the option to submit present or future differences to arbitration. In other words, in order to be valid and binding, such agreement must be bilateral and not unilateral.

The defendant observed that the consent of the plaintiff had been given in advance for submission to arbitration. Such consent makes this clause bilateral and not unilateral. This previous consent will bind the plaintiff throughout. In this case, the plaintiff entered into this agreement after going through the contents of the arbitration clause and thus bound himself with the same. Since disputes have arisen the matter has to be referred to arbitration. It is incorrect on the part of the plaintiff to allege that it is a unilateral clause. The

12Baron v. Sunderland Corporation, All England Report 1966(1) 349(351).

13Union of India v. Ratilal R. Taunk, 2nd (1966) ILR 2 Cal 527

14 The Arbitration and Conciliation Act, 1996. 
Court however did not accept the defendants' argument and held that, no valid agreement existed in the absence of mutuality and presence of conditional clauses.

\section{2 Emmsons International Case}

The Delhi High Court with its decision in 2005 in the case of Emmsons International Ltd. v. Metal Distributors ${ }^{15}$ confirmed its stance on unilateral option clauses. The clause in dispute reads as follows:

Governing Law and Forum for Resolution of Disputes This contract shall be construed in accordance with and governed by English Law. Sellers (Metal Distributors) shall be entitled at their opinion, to refer any dispute arising under this contract to arbitration in accordance with the rules and regulations of the London Metal Exchange or to institute proceedings against buyers (Emmsons Int.) in any Courts of competent jurisdiction. ${ }^{16}$

The argument of the plaintiff was that the clause was not operational by the virtue of Section 28 of the Contract Act ${ }^{17}$ and it was opposed to public policy.

The above section renders void, those agreements which absolutely restrict a party to a contract from enforcing the rights under that contract in ordinary courts. The court opined that, since the clause imposes an absolute restriction on the right of the plaintiff to approach either any ordinary tribunal or before any alternate dispute resolution mechanism, it is hit by Section 28 of the Contract Act ${ }^{18}$ other than being against public policy.

But, the significant part to note in this decision is, 'had it been a case where the restriction imposed by the contract was against the enforcement of the rights of the buyer before the ordinary tribunals, but, the agreement had provided for a section of several ordinary tribunals in which ordinarily a suit would lie, the

\footnotetext{
${ }^{15}$ Emmsons International Ltd. v. Metal Distributors,(2005) BC 465. ${ }^{16} I d$.

17 Indian Contract Act, 1872.

${ }^{18}$ Id.
} 
defendant would have been within its right to enforce such an agreement.' 19

The author concludes that, this judgment while rejecting the clause in question, establishes a much important distinction between absolute bar and partial bar to remedy. The observation of the court can be construed as meaning that if the buyer had a right to approach either an ordinary tribunal or arbitration, the clause would not have been against Section 28 of the Contract Act ${ }^{20}$. Thus, even if the seller had a broader choice, it would still be a valid clause as the buyer was not denied his right to seek justice. Therefore, this judgment concludes that a clause which gives one party a broader choice, while the other can still access justice, is a valid clause.

\section{3 Castrol India}

The dispute between Castrol India Ltd. v. M/s. Apex Tooling Solutions ${ }^{21}$ before the Madras High Court was with regard to the possible bias of the arbitrator who was an employee of Castrol. Castrol contended that, based on the requirements of a valid arbitration clause as given in Section 7 of the Arbitration and Conciliation Act ${ }^{22}$, the existence of the clause was not disputed. What was disputed was, the appointment of the Marketing Director of the Corporation or of some officer of the Corporation who may be nominated by the Director as the arbitrator. The clause was as follows:

In case any dispute or difference shall at any time arise between the Company and the Distributor as to the construction, meaning or effect of this Agreement or any clause or thing contained herein or the rights and liabilities of the parties hereto in relation to the premises hereunder, the Company alone (sic) shall have the right to exercise any of the following two options-

\footnotetext{
${ }^{19}$ Emmsons International Ltd. v. Metal Distributors, (2005) BC 465.

20 Indian Contract Act, 1872.

${ }^{21}$ Castrol India Limited v. M/sApex Tooling Solutions, Application no. 5597 of 2013 in C. S. No. 162 of 2013.

22 The Arbitration and Conciliation Act, 1996.
} 
i. To approach the Court of competent jurisdiction only in the city where this Agreement is entered into;

ii. To refer such dispute or difference to the Arbitration of the Managing Director of the Company. The Arbitration proceedings will be conducted in accordance with the provisions of the Arbitration and Conciliation Act, 1996 and the venue of the Arbitration will be Mumbai only." 23

The validity of the reference to arbitration has been argued on two fronts - that, Section 7 does not make the existence of bilateral reference compulsory and that, mutuality of parties to initiate a reference is not a pre-condition.

The plaintiff referred to 'Russel on Arbitration'24, opining that there was no requirement under English Law for an arbitration agreement to confer on the parties a mutual right to initiate a reference, and an arbitration agreement providing an option for one party alone to refer disputes to arbitration was valid. ${ }^{25}$ While discussing the unilateral option to litigate, it has been observed that the option to litigate to one party would be upheld, provided it is clear and unequivocal. Naturally, while one party has a choice of litigating or arbitrating any dispute, the other party can be forced to arbitrate. ${ }^{26}$ 'Commercial contracts occasionally give a unilateral right of arbitration. Sometimes they state that claims by one party are to be the subject of arbitration, whereas claims by the other are not. In other cases, one party has an option to call for arbitration, whilst the other party does not. Such clauses are recognised by the Court as binding. ${ }^{27}$

${ }^{23}$ Castrol India Limited v. M/sApex Tooling Solutions, Application no. 5597 of 2013 in C. S. No. 162 of 2013.

${ }^{24}$ DAVID SutTON, Judith GILl \& MAthew GeARING, Russel ON ARBITRATION 217 (Sweet \& Maxwell, 23 ${ }^{\text {rd }}$ ed. 2014).

${ }^{25}$ NB Three Shipping Ltd. v. Harebell Shipping Ltd. [2005] 1 Lloyd's Rep. 509.

26DAVID Sutton, JUdith GILl \& MATHEW GEARING, Russel ON ARBITRATION 218 (Sweet \& Maxwell, 23rd ed. 2014).

${ }^{27}$ LORD Mustill\&Mr. BOYD, THE LAW AND PRACTICE OF COMMERCIAL ARBITRATION IN ENGLAND (1989). 
The counsel for the appellants emphasises on the international practice followed in such matters, where in, arbitration clause need not necessarily have mutuality. This is the current trend in England and Australia. The judgments are quite clear on this aspect. ${ }^{28}$ The view adopted is that, conferment of discretion to pick either arbitration or the courts as the form of resolution of disputes was not bad as per law. There is no doubt that Indian arbitration law being in conformity with the UNCITRAL Model, construction ought to be given to the statute and the clauses under it in conformity with international practices. ${ }^{29}$ However, this case was not referred to arbitration by the High Court. The respondent had sent notice to the appellant conveying their intention to prosecute and the intention to arbitrate was not conveyed to the respondent. Thus, the court could not undermine the position of the respondent and dismissed the appeal to refer to arbitration. This case establishes the lack of a need for mutuality as has been followed in England from the beginning and recently in other parts of the world. This judgement encourages us to interpret the Indian laws according to the international practice as arbitration all over the world is drawn from the UNCITRAL model, as it is in India. The General Assembly of the United Nations has recommended that all countries give due consideration to the said model, in view of the desirability of uniformity in the law of arbitral procedures and specifically international commercial arbitration. ${ }^{30}$

\subsection{Fuerst Day Lawson $v$. Jindal Exports}

The Delhi High Court in this case ${ }^{31}$ examined the validity of the unilateral option clause in dispute between the buyer and the seller. The petitioner argued that the clause lacked mutuality and was unilateral, while the respondent argued for its validity. The court raised the issue whether an agreement between two persons can confer on one of them alone, the right to refer the matter to arbitration. This is a fully bilateral agreement which constitutes a

\footnotetext{
${ }^{28}$ Supra note 25.

${ }^{29}$ Castrol India Limited v. M/sApex Tooling Solutions, Application no. 5597 of 2013 in C. S. No. 162 of 2013.

30 The Arbitration and Conciliation Act,Preamble, 1996.

31Fuerst Day Lawson Ltd. v. Jindal Exports Ltd., 11 December, 2009.
} 
contract. The fact that the option is exercisable by only one of the parties is irrelevant. The arrangement suited both parties and they agreed upon it. ${ }^{32}$ Mutuality was an essential condition in arbitration contracts until $1986^{33}$ as established by the English Courts. The Bench opined that, even if the English law did not apply, then also upon a proper construction of the disputes resolution mechanism, there was an irrevocable open offer by the grantor of the option, namely, the petitioner, to submit disputes to arbitration and the power of acceptance vested in the option holder namely, the respondent. When the option was exercised and the offer accepted, the arbitration mechanism became mandatory with full implications thereof. Thus, the petitioners' submissions that there was no legally valid arbitration agreement, is contrary to the facts of the case and untenable in law. ${ }^{34}$

The Supreme Court in the Renusagar Case $e^{35}$ has observed that public policy should be construed narrowly. Where there is an arbitration agreement between parties, effect must be given to the intention of the parties. Only when something is grossly against the fundamental policy of Indian law or its interests, justice, or morality, can it be said to be against public policy. ${ }^{36}$ Thus, this case goes on to establish that unilateral clauses are valid relying upon a vast spread of judgements brought forward by both parties. The observations made by the High Court of Bombay addresses the main areas of dispute regarding mutuality, unilaterality of the clause, and violation of public policy. However, in the absence of a clear stance by the Supreme Court, the contradictory rulings of the High Court's offer no solace to the parties wanting to ensure their rights under the unilateral option clauses.

${ }^{32} I d$.

33Pittalis v. Shorefettin, (1986) 1QB 868.

34Fuerst Day Lawson Ltd v. Jindal Exports Ltd.,11 December, 2009.

${ }^{35}$ Renusagar Power Co. Ltd. v. General Electric Co., AIR 1994 SC 860.

${ }^{36} I d$. 


\section{Comparing Decisions of Courts around the World}

The comparison of some of the decisions of Courts across the world which have ruled for and against the validity of the unilateral option clause will be helpful. It will facilitate the examination of the reasons for enforcing/not enforcing these clauses in those countries and see how their operation will affect the validity of the unilateral option clause in India.

\subsection{Procedural Equality - Russia}

In June 2012, the Russian Supreme Commercial Court found a unilateral dispute resolution clause to be contrary to the basic principle of procedural equality of the parties, adverse to the nature of the dispute resolution process, and in breach of the balance between the interests of the parties. ${ }^{37}$ The dispute, between Russian telecommunications company RTK and a Russian subsidiary of Sony Ericsson, arose over a clause that provided generally for arbitration in London under ICC rules, but reserved for Sony the right to apply to any competent court.

The Indian Arbitration Act, 1996 recognises equal treatment of parties, ${ }^{38}$ however, this is with regard to having equal opportunity in presenting their case. The Russian concept of procedural equality is actually not in contradiction with validity of unilateral option clauses in India because the parties are treated equally once the reference is made. It is only at the time of making the reference that one party has a right over the other.

\subsection{Potestative Condition - France}

The French Cour de Cassation in the Rothchilds case ${ }^{39}$ held that, a unilateral option clause is void for creating a 'potestative condition' contrary to French law. A potestative condition is one that makes the performance of the agreement dependent on the occurrence of

\footnotetext{
37 CJSC Russia Telephone Company (RTC) v. Sony Ericsson Communication Rus LLC, Case no. VAS-1831/12.

38 Arbitration and Conciliation Act, § 18, 1996.

${ }^{39} \mathrm{X}$ v.BanquePrivée Edmond de Rothschild Europe, Cass. Civ. (1ère) Sept. 26, 2012.
} 
an event that can be brought about only by one of the contracting parties. The French courts said that, the clause in question was also against the Brussels Regulation ${ }^{40}$. However, this decision has been widely criticised by media and commentators ${ }^{41}$ as the European Court of Jurisdiction (ECJ) is supposed to interpret the Brussels Regulation as it applies across the European Union (EU). The validity of Article 23 should be assessed with reference to the autonomous requirements of this Article and not in reference to concepts under the laws of the member States. ${ }^{42}$ In addition, the legislative intent behind Article 23 was with respect to the 'autonomous will' of the parties. ${ }^{43}$

In a subsequent decision ${ }^{44}$ in 2013 , in his defence of unilateral jurisdiction clauses, Justice Popple referred to the French decision in Rothschild case as 'controversial'. In 2014, the Luxembourg District Court also upheld the use of a unilateral jurisdiction clause under Article 23 of the Brussels Regulation, and refused to follow the reasoning of the Rothschild case, noting that the precursor to Brussels I, expressly permitted such clauses.45 With another decision in 201546, French Courts ruled unilateral option clauses as invalid.

40 Brussels Regulation I, Art. 23, 2000, http://eur-lex.europa.eu/legalcontent/EN/TXT/?uri=celex\%3A32001R0044.

41Sarah Garvey, The end of the road for "one-way" jurisdiction and arbitration clauses, http://www.allenovery.com/publications/en-gb/lrrfs/ continental\%20europe/Pages/The-end-of-the-road-for-one-wayjurisdiction-and-arbitration-clauses-.aspx.

42ElefantenSchuh GmbH v.Jacqmain, (1981) ECR 1671.

43 Commission of the European Communities (1999) 348, 18, http://www.statewatch.org/semdoc/assets/files/commission/COM1999-348.pdf.

${ }^{44}$ Mauritius Commercial Bank Limited v. Hestia Holdings Limited \& Another,(2013) EWHC 1328.

45Marie Berard, Clifford Chance - Unilateral Option Clauses in Arbitration: Survey (Jan. 2017), https:// www.cliffordchance.com/ briefings/ 2017/ 01/unilateral_optionclauses-2017survey.html.

${ }^{46}$ Dannev.Crédit Suisse,[2015] Cass. Civ. (1ère) 13-27, 264. 
In conclusion, the French position on unilateral option clause is with respect to 'potestative condition' which is not recognised by the Indian Courts. Thus, the French reasoning is irrelevant to the Indian context. However, it has been argued in Indian Courts that unilateral option clauses do not have a binding clause because only on the choice of one of the parties, the matter can be considered by arbitration. It is also argued that, such agreements are usually meant for future arbitration. However, the Bombay High Court successfully distinguishes this while observing that even a conditional (or optional) agreement to refer future disputes to arbitration, is nevertheless an agreement to refer future disputes within the clause. It is a binding agreement and it requires the parties to refer a future dispute to arbitration, whenever a valid election is made. Although, there is no reference of any particular dispute until such an agreement does come into existence, there can be an actual reference only after the dispute has arisen. Before that, there can only be an agreement that future disputes will be referred, and the fact that such an agreement depends upon the exercise of an option, even by the party claiming arbitration, does not prevent this from being an agreement within the clause. ${ }^{47}$

\subsection{Mutuality And Optionality - Singapore}

The most recent international decision on the validity of unilateral option clause is this case ${ }^{48}$, in which the validity of the arbitral clause was challenged on three fronts as is usually done in all cases:

a) 'whether there is a valid arbitration agreement between the parties to the court proceedings;

b) Whether the dispute in the court proceedings (or any part thereof) falls within the scope of the arbitration agreement;

c) Whether the arbitration agreement is not null and void, inoperative, or incapable of being performed.'

In this case, upon dispute, Dyna-Jet chose litigation as a method of dispute resolution while Hestia Holdings tried to obtain a stay on the proceedings. It was presented before the Singaporean Court

47Fuerst Day Lawson Ltd. v. Jindal Exports Ltd.,11 December, 2009. 48Wilson Taylor Asia Pacific Pte Ltd.v.Dyna-Jet Pte Ltd., (2017) SLR 3267. 
(SCGA) to determine whether the stay can be granted. Since, the stay could only be granted on a valid arbitration agreement, they set to inspect the validity of this arbitration clause. The clause in dispute was as follows:

Any claim or dispute or breach of terms of the Contract shall be settled amicably between the parties by mutual consultation. If no amicable settlement is reached through discussions, at the election of Dyna-Jet, the dispute may be referred to and personally settled by means of arbitration proceedings, which will be conducted under English Law; and held in Singapore. 49

With respect to the first issue, the High Court held that, a contractual dispute resolution agreement which operates asymmetrically and grants a right to choose whether to arbitrate a future dispute is nevertheless an arbitration agreement. ${ }^{50}$ On the weight of the modern Commonwealth authority, which the Judge considered, neither of these features prevented the court from finding that there was a valid arbitration agreement between the present parties. The SGCA agreed on these observations of the High court regarding 'mutuality' and 'optionality' of the clause.

With regard to the second issue, the clause did not place the parties under a present obligation to arbitrate, but, would give rise to an arbitration agreement only if and when the respondent elected to arbitrate a specific dispute in the future. On this basis, the dispute could have fallen within the scope of the clause only if the respondent had so elected. In the absence of such an election, in the words of Section 6(1) of the International Arbitration Act, the dispute in the present circumstances was not a 'matter which is the subject of the agreement'. ${ }^{51}$ The third question of validity was not discussed as the subject matter was not within the scope of the agreement.

When this decision is examined from the Indian perspective, the interpretation adopted by Justice Coomaraswamy was consistent

${ }^{49} I d$.

${ }^{50} I d$.

${ }^{51} I d$. 
with Section 2A of the International Arbitration Act that, it does not require an arbitration agreement to refer all future disputes to arbitration or to do so unconditionally. ${ }^{52}$ The same holds true in Indian law. Indian law does not hold the position that, optionality or lack of mutuality will render an arbitration clause void. Thus, it is safe to say that, if the contents of a carefully drafted unilateral option clause do not contradict statutory law and are not unconscionable to the extent that they threaten the very purpose of the clause, these clauses should be held valid under Indian law.

\subsection{Illusory Arbitration Clause - Texas}

The case NACE $v$. Maurice Johnson and E \& M Enterprises, Inc. ${ }^{53}$ shows that, as long as the arbitration clause is not illusory, it is capable of enforceability. The fact that only one party can elect a forum is no reason to hold an arbitral clause to be invalid. An arbitration clause is not illusory unless one party can avoid arbitration by amending the provision or terminating it altogether. ${ }^{54}$ The arbitration agreement does not empower either party to avoid arbitration, nor does it afford either party unilateral authority to amend, change, or terminate the arbitration clause. 55 This principle is worth noting because Indian courts rely heavily on certainty and finality of the arbitration clause. Thus, as long as neither party can avoid arbitration and has to go through with the proceedings once it has been elected by one of the parties to the unilateral option clause, the result of the arbitration is binding on them. None of the parties on choosing arbitration can seek to avoid it or terminate that agreement.

'The intention of the parties to enter into an arbitration agreement shall have to be gathered from the terms of the agreement. If the terms of the agreement clearly indicate an intention on the part of the parties to the agreement to refer their disputes to a private tribunal for adjudication and a willingness to be bound by the

${ }^{52} I d$.

${ }^{53}$ NACE v. Maurice Johnson and E \& M Enterprises, Inc., No. 01-15-00529CV.

${ }^{54}$ In re 24R, Inc., 324 S.W.3d 564, 567 (Tex.2010).

${ }^{55}$ Royston, Rayzor, Vickery, Williams v. Lopez, 467S.W.3d. 
decision of such tribunal on such disputes, it is an arbitration agreement. While there is no specific form for an arbitration agreement, the words used should disclose determination and obligation to go to arbitration and not merely contemplate the possibility of going for arbitration. Where there is merely a possibility of the parties agreeing to arbitration in future, as contrasted from an obligation to refer disputes to arbitration, there is no valid and binding arbitration agreement. ${ }^{56}$

\section{Conclusion}

The dilemma that we face, is regarding equality and mutuality of parties in arbitration. The question before Indian Courts is whether equality of parties is respected as long as neither party has to let go of their claim or is there a need for equality in initiating reference of claim before a particular forum. Section18 provides for equal treatment of parties. ${ }^{57}$ However, that is with respect to each party having an opportunity of presenting its case. The Indian Arbitration Act, 581996 does not talk about equal treatment of parties to approach the tribunal. Unilateral option clause merely confers a procedural advantage for a party to optimize its position in anticipation of legal disputes. The parties have equal substantive rights under law. While procedural rights regulate where and how a dispute may be resolved, the dispute would ultimately be determined in accordance with the parties' substantive legal rights. The arbitration agreement is usually in the form of an arbitration clause embodied in the main contract. The clause does not stand alone; it is part of an underlying contract. As a result, consideration - the presence of mutual obligation - is provided by the underlying contract. 59

The agreement to refer to arbitration is in the form of, or a part of a contract. Thus, it has to adhere with basic principles of validity of a contract, which are competency of parties, lawful consideration,

\footnotetext{
56JagdishChanderv. Ramesh Chander and Ors., 2007(2) Arb. L.R. 302.

57 Arbitration and Conciliation Act, § 18, 1996.

58 Arbitration and Conciliation Act, 1996.

${ }^{59}$ AdvancePCS,172 S.W.3d at 607; Palm Harbor, 195 S.W.3d at 676.
} 
lawful object, etc. 60 However, the Indian Contract Act,1872 nowhere disregards a contract with disproportionate consideration as long as it is by the consent of the parties, in the absence of undue influence and fraud.61 Thus, the question is whether equal consideration does not make the contract void. Under such circumstances unequal bargaining power in the approaching forum should also not do so, as long as there is an indication of consensus ad idem. The rights of the parties in arbitration are created by the contract, thus, the parties should be free to choose the extent of their rights as long as it does not contradict with the operation of law. Nothing in the essentials of arbitration clause ${ }^{62}$ invalidates unilateral option clauses. Nor does such a clause take away the right of a party to voice its grievances and seek remedy for the same. Thus, the author finds no reason why such clauses should not be recognised in India.

${ }^{60}$ Indian Contract Act, § 11, 1872.

${ }^{61}$ Indian Contract Act, § 14, 1872.

62Arbitration and Conciliation Act, § 7, 1996. 